\title{
Metadata to the database on fish distribution in Italian lakes and reservoirs
}

Pietro Volta \& Silvia Galafassi
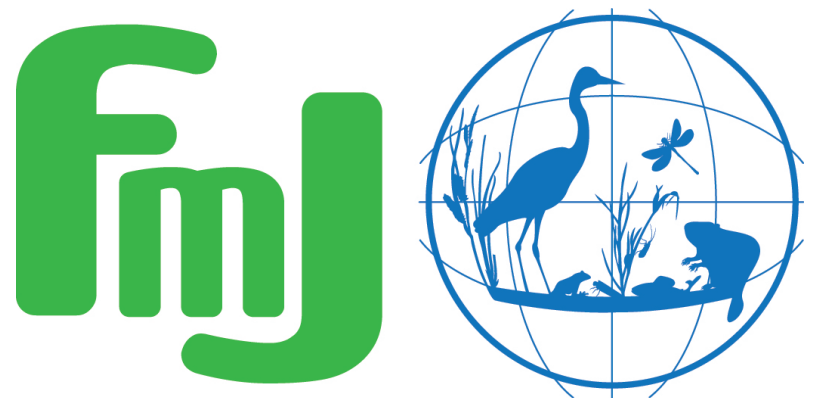

Freshwater Metadata Journal 



\title{
Metadata to the database on fish distribution in Italian lakes and reservoirs
}

\author{
Pietro Volta ${ }^{1} \&$ Silvia Galafassi ${ }^{1}$ \\ 1 CNR IRSA Water Research Institute, Verbania, Italy; corresponding author: pietrovolta@gmail.com
}

Please cite this paper as follows: Volta, P. \& Galafassi, S., 2018. Metadata to the database on fish distribution in Italian lakes and reservoirs. Freshwater Metadata Journal 35: 1-5.

https://doi.org/10.15504/fmj.2018.35

Received: 2018-09-07 / Published: 2018-09-28

\section{Keywords}

fish biodiversity, multimesh gillnet, WFD 2000/60/EC, lakes, reservoirs

\section{Short description of the dataset/summary}

The database comprises the distribution of freshwater fish species in 28 Italian lakes. Data were obtained between 2007 and 2014 from standardised (CEN based) samplings with benthic and mesopelagic multi-mesh gillnets. The database offers a detailed description of the biodiversity of fish communities in the Italian regions of Piedmont, Lombardy, Trentino-Alto Adige and Sardinia including both natural lakes and reservoirs.

\section{Short description of the dataset/summary (original/national language)}

Il dataset include le informazioni sulla distribuzione della fauna ittica in 28 laghi italiani. Le informazioni raccolte sono basate su campionamenti con reti multimaglia bentiche e pelagiche in accordo con la metodologia CEN e il protocollo nazionale utilizzato per l'applicazione della Direttiva Quadro sulle Acque 2000/60/CE.

\section{General information}

dataset entry ID: $\quad$ FWM_19

\section{name of the dataset:}

full name of the dataset: $\quad$ Fish distribution in 28 Italian lakes based on CEN gillnets

full name of the datast (original/national language):

type of dataset: $\quad$ species distribution data

data type: point data/observation data

science keywords according to GCMD:

topic:

Biosphere, Biological Classification, Climate Indicators, Terrestrial 
Hydrosphere

ISO topic category according to ISO 19115:

Biota, Environment, Inland Waters

INSPIRE keywords according to GEMET:

Species distribution

own science keywords:

freshwater fish; Italy; lakes; non native fish species

related project:

LIFE+ Inhabit, WISER, CENSIMENTO DELLA FAUNA ITTICA DEI

LAGHI SUDALPINI

funding:

INHABIT - LIFE08 ENV/IT/000413.

WISER - European Union, 7th Framework Programme, Theme 6

(Environment including Climate Change) (contract No. 226273).

CENSIMENTO DELLA FAUNA ITTICA DEI LAGHI SUDALPINI -

REGIONE LOMBARDIA.

\section{Technical and administrative specifications}

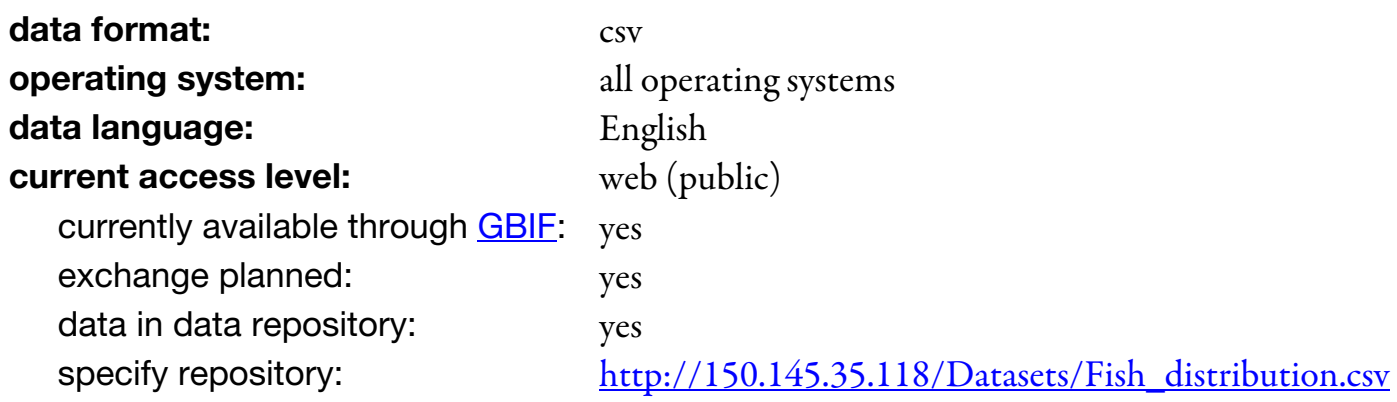

Do you plan to publish the data on the Freshwater Biodiversity Data Portal:

$\begin{array}{ll}\text { update level: } & \text { completed } \\ \text { documentation: } & \\ \text { type: } & \text { manual } \\ \text { language: } & \text { English }\end{array}$

\section{contact details:}

metadata contact person:

first, last name:

Pietro Volta

phone:

+390323518335

email:

institution:

p.volta@cnr.it

address:

CNR IRSA Water Research Institute

postal code, city:

Largo Tonolli 50

28922 Verbania

province, state:

VB

country

Italy

web address:

http://www.irsa.cnr.it/

technical contact person:

first, last name:

Silvia Galafassi

phone:

+390323518300

email:

scientific contact person:

first, last name:

silvia.galafassi@gmail.com

Pietro Volta

phone:

+390323518335 
email:

p.volta@cnr.it

\section{Intellectual property rights and citation}

dataset creator (data compiler):

contact name:

contact email:

Pietro Volta

contact institution:

p.volta@cnr.it

Water Research Institute IRSA - Consiglio Nazionale delle Ricerche

data contributors to/owners of this dataset:

single

criteria for using this dataset: The dataset is publicly available (data portal, data archive) and can be used without restrictions, but dataset creator/data contributors must be informed prior to publication. Data must be acknowledged and cited correctly.

citation of this dataset:

author(s):

Volta, P. \& Galafassi, S.

title and journal (name, number, pages):

Database on fish distribution in Italian lakes and reservoirs.

year: $\quad 2018$

doi: $\quad$ https://doi.org/10.15468/uey35v

citation of the metadata:

author(s):

Volta P. \& Galafassi S.

title and journal (name, number, pages):

Metadata to the database on fish distribution in Italian lakes and reservoirs.

Freshwater Metadata Journal 35: 1-4

year: $\quad 2018$

doi: $\quad$ https://doi.org/10.15504/fmj.2018.35

\section{General data specifications}

regional coverage of the dataset:

spatial extent of the dataset: national

continents: Europe

spatial extent (bounding coordinates):

southernmost latitude $\left[{ }^{\circ}\right]$ : $\quad 40.553089$

northernmost latitude $\left[^{\circ}\right]$ : $\quad 46.756744$

westernmost longitude $\left[{ }^{\circ}\right]$ : $\quad 7.125792$

easternmost longitude $\left[^{\circ}\right]$ : $\quad 12.085461$

minimum altitude: $\quad 43$ metres

maximum altitude: 2275 metres

countries: $\quad$ Europe: Italy

world climatic regions according to Köppen:

Group C: temperate/mesothermal climates

Group D: continental/microthermal climate

Group $\mathrm{H}$ : alpine climates

European ecoregions according to Illies (WFD):

ecosystem type:

covered timeframe:
Italy, Corsica and Malta (ER3)

lakes/ponds

$2007-2014$ 


\section{Site specifications}

coordinate system/grid data:

datum (e.g. WGS84):

grid data available:

number of sites:

exact number of sites: latitude/longitude, format: DD

projected, UTM

WGS84

no

$<100$

28

\section{Biological data}

biological data origin:

organism group addressed:

from sampling, INHABIT - LIFE08 ENV/IT/000413. WISER - European Union, 7th Framework Programme, Theme 6 (Environment including Climate Change) (contract No. 226273). CENSIMENTO DELLA FAUNA ITTICA DEI LAGHI SUDALPINI - REGIONE LOMBARDIA fish

\section{Sample resolution}

fish:

\section{taxonomic resolution:}

level: $\quad$ species

percentage of species level data: 100

\section{taxonomic coding:}

taxalist according to: reference(s):

Kottelat and Freyhof

Kottelat, M. and J. Freyhof, 2007. Handbook of European freshwater fishes. Publications Kottelat, Cornol and Freyhof, Berlin. 646 pp.

\section{sample specifications:}

specification of method(s) used for sampling and sorting:

According to the depth and surface area of the lake, an appropriate number of benthic and pelagic multi-mesh gillnets were used, following CEN standards partly modified. Each benthic net was $40 \mathrm{~m}$ long and $1.5 \mathrm{~m}$ high and was composed of 16 panels (each $2.5 \mathrm{~m}$ long) with mesh sizes ranging from 5.5 to $135 \mathrm{~mm}$. The benthic nets were set from the surface down to $100 \mathrm{~m}$ depth. Pelagic sampling was performed with a variable number of nets linked together, each being $27.5 \mathrm{~m}$ long and $6 \mathrm{~m}$ high and having 11 panels (with a mesh size ranging from $8 \mathrm{~mm}$ to $55 \mathrm{~mm}$, knot to knot). Four additional nets ( $40 \mathrm{~m}$ long, 6 $\mathrm{m}$ high, 4 panels $(75,95,115$ and $135 \mathrm{~mm})$ ) were attached to the end of each pelagic net set. The nets were set at $10 \mathrm{~m}$ intervals from the surface down to 50 $\mathrm{m}$ depth. Nets were set at dusk between 16.00 and $20.00 \mathrm{pm}$ and lifted the following morning between 06.00 and $08.00 \mathrm{am}$.

reference(s): CEN. Water quality?Sampling of fish with multi-mesh gillnets (English version prEN 14757:2013). Brussels: European Committee for Standardization; 2005. ISPRA. 2014. Metodi biologici per le acque superficiali interne. Manuali e linee guida 111 / 2014. Rome, Italy. ISBN 978-88-448-0651 


\section{Other specifications}

GIS layers, shape files related to the dataset:

$\begin{array}{ll} & \text { no data available } \\ \text { availability of photos: } & \text { no } \\ \text { availability of maps: } & \text { no }\end{array}$

quality control procedures:

Were any quality control procedures applied to your dataset?

no

\section{Acknowledgements}

The authors aknowledge all the colleagues and people contributing with their help to the fish sampling campaigns. Pietro Volta was funded by FP7 WISER, Inhabit LIFE08 ENV/IT/000413 and IdroLIFE LIFE15 NAT/IT/000823. 